\title{
Enhancing the Reliability of MODIS Gross Primary Productivity (GPP) by Improving Input Data
}

\author{
Young-Il Kim ${ }^{1}$, Sinkyu Kang ${ }^{2 *}$, and Joon Kim ${ }^{3}$ \\ ${ }^{1}$ Department of Geography, McGill University, Montreal, Canada \\ ${ }^{2}$ Department of Environmental Science, Kangwon National University, Chuncheon 200-702, Korea \\ ${ }^{3}$ Department of Atmospheric Sciences, Yonsei University, Seoul 120-749, Korea
}

(Received March 12, 2007; Accepted June 11, 2007)

\section{입력자료 개선에 의한 MODIS 총일차생산성의 신뢰도 향상}

\author{
김영일 ${ }^{1} \cdot$ 강신규 $^{2 *} \cdot$ 김 준 $^{3}$ \\ ${ }^{1} \mathrm{McGill}$ 대학교 지리학과, ${ }^{2}$ 강원대학교 환경과학과, ${ }^{3}$ 연세대학교 대기과학과 \\ (2007년 3월 12일 접수; 2007년 6월 11일 수락)
}

\begin{abstract}
The Moderate Resolution Imaging Spectroradiometer (MODIS) regularly provides the eight-day gross primary productivity (GPP) at $1 \mathrm{~km}$ resolution. In this study, we evaluated the uncertainties of MODIS GPP caused by errors associated with the Data Assimilation Office (DAO) meteorology and a biophysical variable (fraction of absorbed photosynthetically active radiation, FPAR). In order to recalculate the improved GPP estimate, we employed ground weather station data and reconstructed cloud-free FPAR. The official MODIS GPP was evaluated as $+17 \%$ higher than the improved GPP. The error associated with DAO meteorology was identified as the primary and the error from the cloud-contaminated FPAR as the secondary constituent in the integrative uncertainty. Among various biome types, the highest relative error of the official MODIS GPP to the improved GPP was found in the mixed forest biome with RE of $20 \%$ and the smallest errors were shown in crop land cover at $11 \%$. Our results indicated that the uncertainty embedded in the official MODIS GPP product was considerable, indicating that the MODIS GPP needs to be reconstructed with the improved input data of daily surface meteorology and cloud-free FPAR in order to accurately monitor vegetation productivity in Korea.
\end{abstract}

Key words : GPP, MODIS, Meteorology, FPAR, Uncertainty

\section{INTRODUCTION}

Vegetation growth is a consequence of atmospheric carbon sequestration into plant biomass, and its role is attracting more attention under global environmental changes including the increase of atmospheric $\mathrm{CO}_{2}$ concentration (Nemani et al., 2003). Hence, the monitoring of vegetation production has been highlighted in many ecological studies (Potter et al., 1993; Churkina et al., 2000; Myneni et al., 2002; Nemani et al., 2003; Morisette et al., 2006; Friend et al., 2007). In global vegetation monitoring, landscape heterogeneity is a serious problem partly because the vegetation production is highly variable both spatially and temporally, which is hardly covered by traditional plot-based surveys (Running et al., 1994). Recent development of satellite remote sensing, however, provides great opportunity for continuous monitoring of global vegetation production (Running et al., 1994; Prince and Goward, 1995; Myneni et al., 2002; Running et al., 2004).

Global productivity can be estimated by combining remote sensing with carbon cycle processing (Heinsch

Corresponding Author: Sinkyu Kang(kangsk@kangwon.ac.kr) 
et al., 2003). The global information on an eight-day total gross primary productivity (GPP) at $1 \mathrm{~km}$ resolution is regularly provided by the Moderate Resolution Imaging Spectroradiometer (MODIS) through the EOS Data Gateway since December, 1999. MODIS GPP has been widely validated by using the eddy-covariance flux tower measurements across multiple biomes in continental and global scales (Heinsch et al., 2006; Turner et al., 2006). For a regional scale application, however, the reliability of the MODIS GPP is somewhat uncertain in terms of potential errors caused by input meteorology, a biophysical variable (i.e., fraction of absorbed photosynthetically active radiation, FPAR), and ecophysiological parameters (Kang et al., 2005a; Zhao et al., 2005 and 2006). The cloud effect on FPAR cannot be ignored, especially in monsoon climate regions such as the Korean Peninsula (Kang, 2005). Furthermore, a degree-by-degree spatial resolution of official input meteorology of the MODIS GPP (i.e., Data Assimilation Office, DAO, provided by NASA) is too coarse to represent the spatial meteorological variation on a regional scale. Hence, careful evaluations of the uncertain factors need be conducted prior to the regular GPP monitoring with the MODIS GPP product.

Recently, uncertainties of the MODIS GPP in Korea, caused by cloud contaminated FPAR and input meteorology, were reported that errors associated with the former and the latter were -8.5 and $+25 \%$, respectively (Kang, 2005; Kang et al., 2005b). In this study, the MODIS GPP uncertainty (related with both FPAR and input meteorology) was evaluated to provide reference information on the gross estimate of the MODIS GPP uncertainty in Korea. Since reliable daily meteorological data were essential for the evaluation, we selected the ground weather stations operated by the Korea Meteorological Administration (KMA) as our study areas, and further reconstructed cloud-free FPAR time series at those weather stations from 2001 to 2003.

\section{MATERIALS AND METHODS}

\subsection{Theoretical backgrounds on MODIS GPP algorithm}

Detailed descriptions on the MODIS GPP algorithm can be found in Heinsch et al. (2003). The algorithm is a biophysical model describing the GPP with the incident PAR and light use efficiency controlled by daily minimum temperature $\left(\mathrm{T}_{\min }\right.$ in $\left.{ }^{\circ} \mathrm{C}\right)$ and atmospheric vapor pressure deficit (VPD in $\mathrm{Pa}$ ) as:

$$
\begin{aligned}
& \text { GPP }=[\varepsilon] \times[\text { FPAR } \cdot \text { PAR }] \\
& \varepsilon=\left[\varepsilon_{\text {max }} \cdot f\left(T_{\text {min }}\right) \cdot f(\text { VPD })\right] \\
& \text { PAR }=\left[0.45 \times R_{s}\right]
\end{aligned}
$$

where $\varepsilon$ is the light use efficiency; $\varepsilon_{\max }$ is the maximum light use efficiency specific to each biome type; and $\mathrm{R}_{\mathrm{S}}$ is a daily incoming shortwave radiation (in $\mathrm{MJ} \mathrm{m}^{-2} \mathrm{~d}^{-1}$ ). PAR was estimated as $45 \%$ of $\mathrm{R}_{\mathrm{s}}$. In the official MODIS GPP, FPAR was provided by the upstream MODIS FPAR/LAI product and the DAO data were utilized for the daily meteorological variables (i.e., $\mathrm{T}_{\text {min }}$, VPD, and $\mathrm{R}_{\mathrm{s}}$ ). Light use efficiency was designed to increase with $T_{\min }$ but decrease with VPD (Heinsch et al., 2003). As shown in the above equations, the quality of both FPAR and the meteorological variables determines the degree of uncertainty in the MODIS GPP.

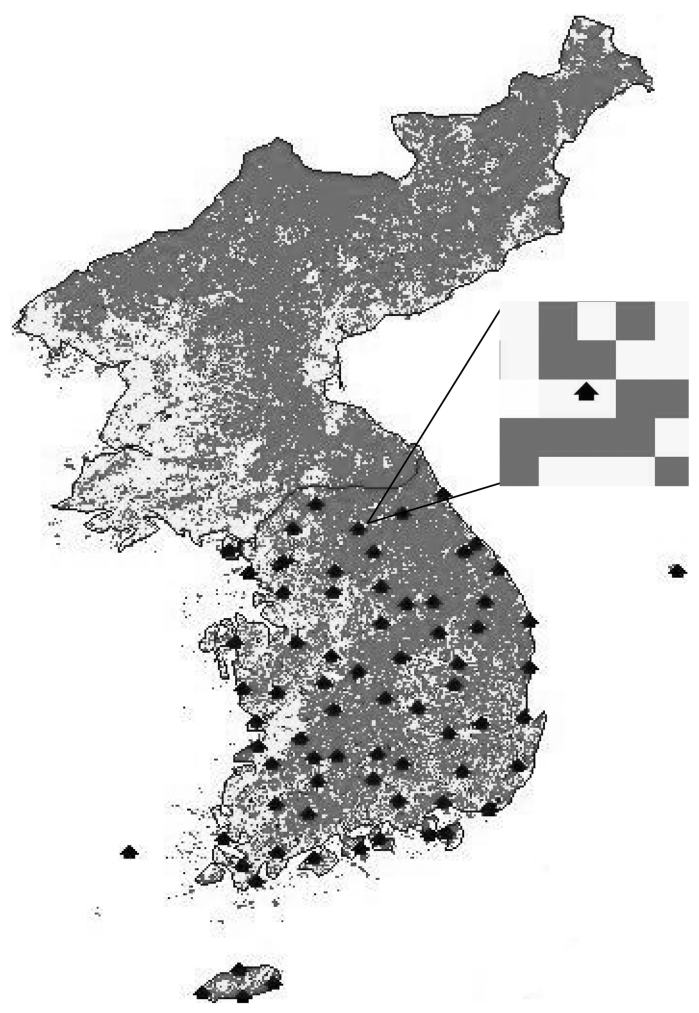

Fig. 1. Locations of national weather stations used in this study. The background is a MODIS land cover map simplified to have forest, crop, and urban land cover types for graphic enhancement. A key map is an example of land cover of $5 \times 5$ pixels around the Chuncheon weather station in 2001 . 


\subsection{Experimental design}

Our study area was selected from 72 National Weather Stations operated by the KMA (Fig. 1). An area of 25 $\mathrm{km}^{2}$ centered on each station was used to reconstruct the cloud-free FPAR and to recalculate the MODIS GPP. Locations of the weather stations were overlaid with 1-km resolution MODIS land cover maps (type 2, UMD classification) and then, 5-by-5 pixels (covering an area of $1,800 \mathrm{~km}^{2}$ ) around each station were selected.

For each pixel of a $25 \mathrm{~km}^{2}$ area, meteorological conditions were assumed identical to the centered weather station but each pixel was recognized with different land covers and FPAR values. Among the 1,800 pixels, mixed forest, deciduous broadleaf forest, needleleaf forest, shrub/savanna, and crop land covers constituted $17,1,2,8$, and $21 \%$, respectively. The remainder of the pixels identified as urban areas was discarded in this study, along with the shrub/savanna pixels because the land cover type is erroneous in Korean landscapes.

For each vegetation pixel, the time series of an 8-day composite MODIS FPAR from 2001 and 2003 were extracted from MODIS FPAR image and then, used to reconstruct cloud-free FPAR time series by using an interpolation method of Kang et al. (2005a). The method uses both land cover information and FPAR values surrounding $5 \times 5$ pixels or the FPAR values of the preceding or following week to mitigate cloud effects on FPAR by interpolation if the pixel of interest is cloud contaminated. If the pixel of interest is identified as cloud contaminated, the method searches cloud free pixels within the $5 \times 5$ pixel window with the identical biome type to calculate the interpolated FPAR of the pixel. If this spatial interpolation fails, then the method searches cloud free FPAR of the preceding and the following week for temporal interpolations of FPAR. The existence of cloud contamination was identified with quality control flags provided with the MODIS FPAR.

The DAO meteorological data were replaced with the weather station meteorological data, with which the effect of uncertainty in input meteorology on the MODIS GPP product was examined. Together with the reconstructed FPAR, the surface meteorological data were utilized to run the MODIS GPP algorithm.

In this study, four different types of MODIS GPP version were calculated with (1) the original MODIS FPAR and official DAO data (named as NON-DAO), (2) the original MODIS FPAR and the surface meteo- rological data (named as NON-NWS), (3) the reconstructed FPAR and official DAO data (named as FILLDAO), and (4) the reconstructed FPAR and the surface meteorological data (named as FILL-NWS). Although our final target was the gross evaluation of the MODIS GPP uncertainty associated with both FPAR and DAO data (i.e., NON-DAO vs. FILL-NWS), the uncertainties were tested step-by-step by correcting each input variable one-by-one. For quantifying the uncertainties, the relative error (RE, \%) was calculated by assuming that the GPP of the FILL-NWS case, surface station data, and reconstructed FPAR were true, while other GPP estimates, DAO data, and original FPAR were uncertain. For example, RE of GPP estimate was evaluated as:

$$
\mathrm{RE}(\%)=\frac{[\text { Other }- \text { GPP }]-[\text { FILL }-\mathrm{NWS}]}{[\text { FILL }-\mathrm{NWS}]} \times 100
$$

In addition to the FAPR and meteorology, there are two more error sources in the MODIS GPP: one is ecophysical parameters specific to biome types and the other is the GPP algorithm itself (Eqs. 1-3). In this study, however, the additional error sources were not evaluated.

\section{RESULTS AND DISCUSSION}

\subsection{Evaluation of DAO data and official MODIS FPAR}

In comparison to the weather station data, the DAO data set underestimated $\mathrm{T}_{\min }$ and VPD by $0.10^{\circ} \mathrm{C}$ and $248 \mathrm{~Pa}$, respectively, and overestimated $\mathrm{R}_{\mathrm{s}}$ by $1.0 \mathrm{MJ}$ $\mathrm{m}^{-2} \mathrm{~d}^{-1}$ for the years from 2001 to 2003 . The values of RE of VPD and $R_{S}$ were $-35 \%$ and $+7 \%$, respectively. The combined effect of the overestimated $R_{s}$ and underestimated VPD caused higher PAR (Eq. 3) and $\varepsilon$ (Eq. 2), resulting in overestimation of GPP (Eq. 1). On the other hand, the underestimated $\mathrm{T}_{\min }$ resulted in the underestimation of GPP by decreasing $\varepsilon$. The net effect on GPP is described later in the following section.

The reconstructed FPAR by mitigating the cloud contamination effect showed more reasonable and smoother seasonal patterns than those of the original MODIS FPAR (Fig. 3). The varying degree of cloud contamination resulted in distinct seasonal variability that was more pronounced in the summer season. Consequently, the summertime RE from June to August was $-15 \%$ but it was about $-3 \%$ in other seasons. For the study area, the three-year mean RE resulted in a 

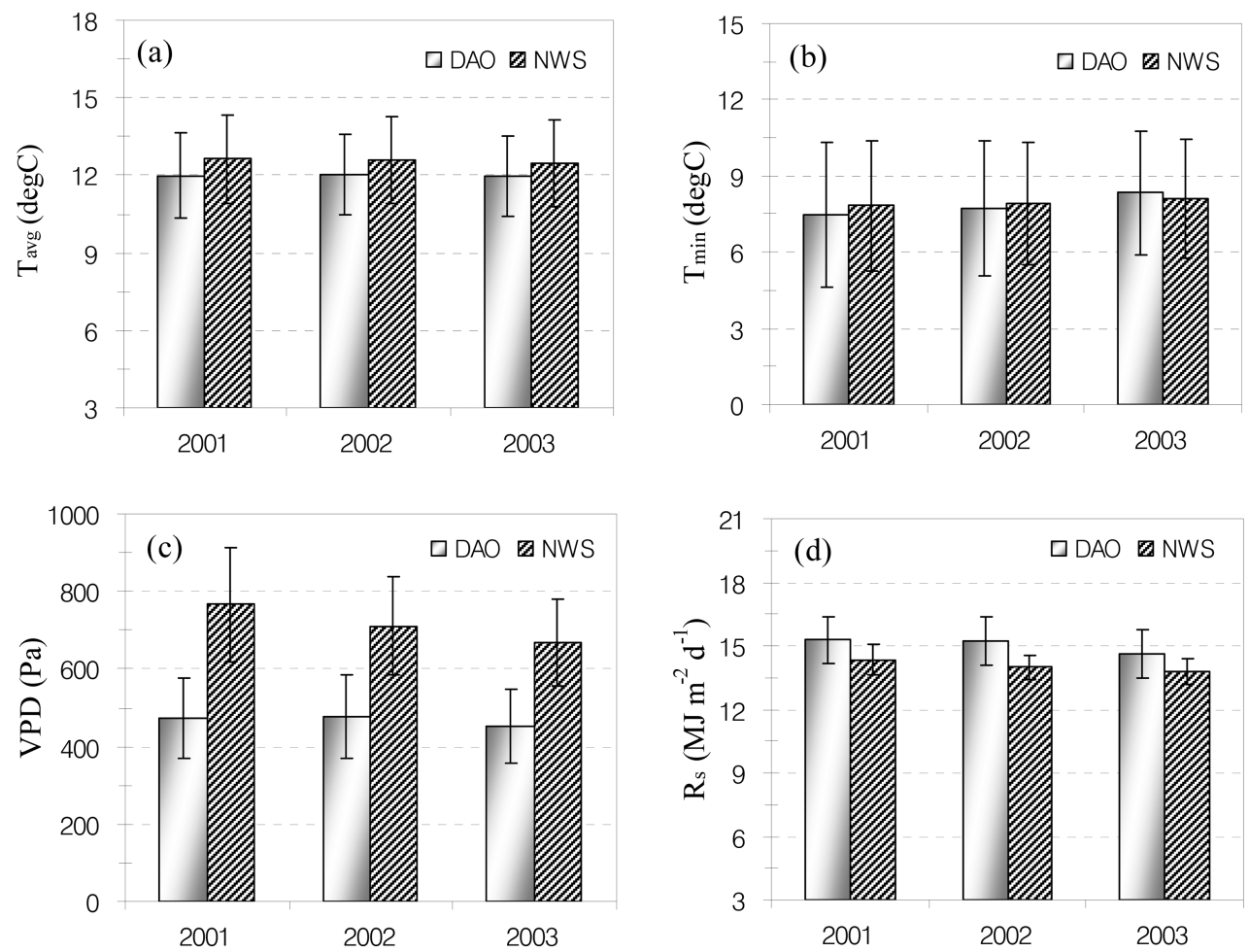

Fig. 2. Comparisons of DAO data with ground meteorological data (NWS) from 72 weather stations: (a) average temperature $\left(\mathrm{T}_{\text {avg }}\right.$ in $\left.{ }^{\circ} \mathrm{C}\right)$, (b) minimum temperature $\left(\mathrm{T}_{\min }\right.$ in $\left.{ }^{\circ} \mathrm{C}\right)$, (c) vapor pressure deficit (VPD in Pa), and incident solar radiation $\left(\mathrm{R}_{\mathrm{s}}\right.$ in MJ m${ }^{-2} \mathrm{~d}^{-1}$ ) from 2001 to 2003 .
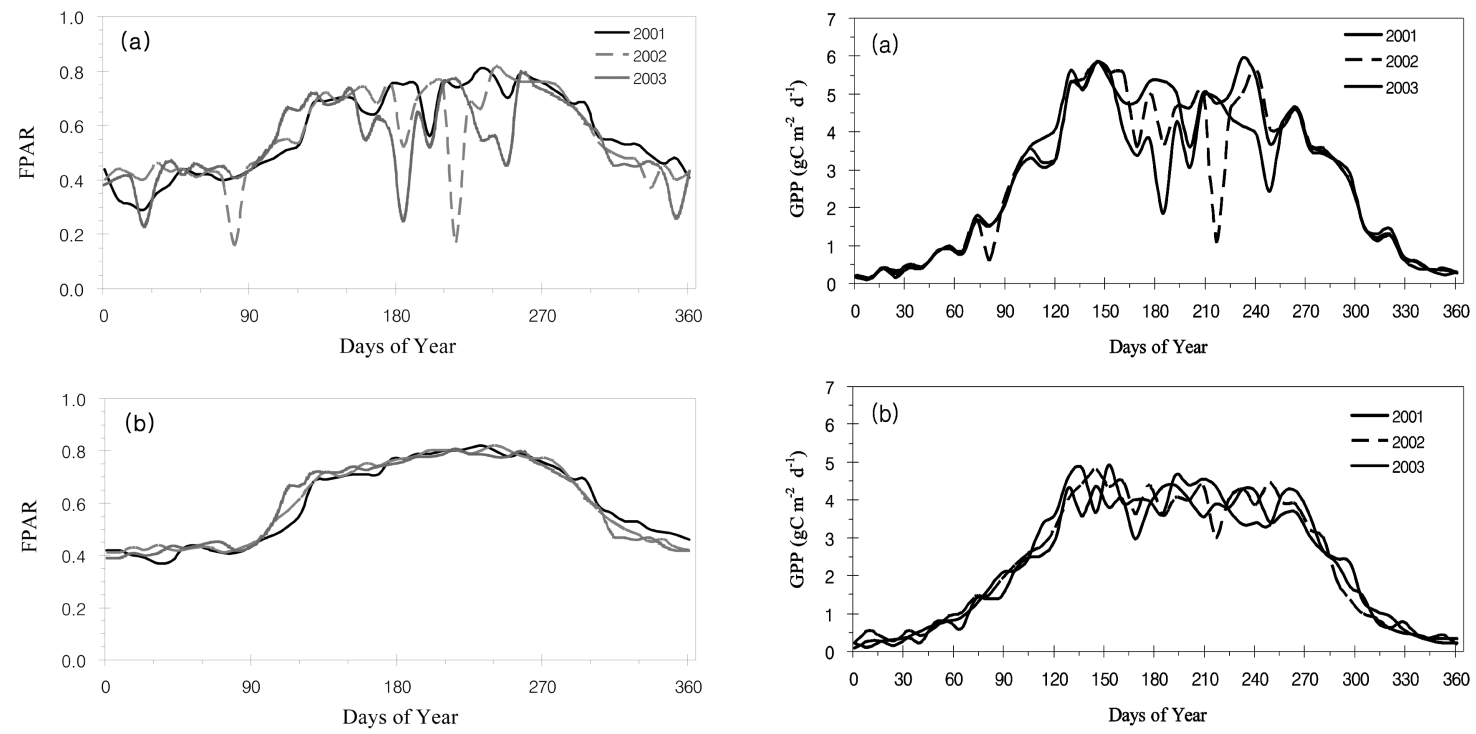

Fig. 3. Eight-day interval time series of the FPAR averaged for vegetation pixels only around 72 weather stations: (a) the original MODIS FPAR and (b) the reconstructed FPAR after cloud correction.

Fig. 4. Eight-day interval time series of the GPP (in $\mathrm{gC}^{-2}$ $\mathrm{d}^{-1}$ ) averaged for vegetation pixels only around 72 weather stations: (a) original MODIS GPP and (b) recalculated GPP after improving input data. 
Table 1. Annual GPP (in $\mathrm{gC} \mathrm{m}^{-2} \mathrm{y}^{-1}$ ) estimated from the original FPAR and DAO meteorology (NON-DAO) and filled FPAR and NWS meteorology (FILL-NWS) for each vegetation type from 2001 to 2003. (Values in parenthesis are the number of pixels of each vegetation type.)

\begin{tabular}{lcccccc}
\hline \hline & \multicolumn{3}{c}{ NON-DAO } & \multicolumn{2}{c}{ FILL-NWS } \\
\cline { 2 - 7 } & 2001 & 2002 & 2003 & 2001 & 2002 & 2003 \\
\hline MF (308) & 1350 & 1378 & 1306 & 1074 & 1132 & 1153 \\
DBF (22) & 1122 & 1219 & 1117 & 1039 & 1109 & 1116 \\
ENF, EBF (34) & 1595 & 1600 & 1548 & 1281 & 1301 & 1258 \\
Crop (373) & 668 & 688 & 668 & 592 & 606 & 623 \\
All & 1009 & 1035 & 989 & 839 & 873 & 889 \\
\hline
\end{tabular}

MX is mixed forest; DBF, deciduous broadleaf forest; ENF, evergreen needleleaf forest; EBF, evergreen broadleaf forest; Crop, crop land.

smaller magnitude $(-7 \%)$ than the one $(-9 \%)$ reported by Kang (2005) for the entire MODIS pixels in Korea. This is probably because most of the weather stations are located at low areas with relatively smooth topography and less cloud covers than complex terrains at high elevations.

\subsection{Uncertainty of MODIS GPP}

For every pixel with vegetation land cover types, seasonal patterns of the official MODIS GPP (NON-DAO) were compared with those from the recalculated GPP (FILL-NWS) by using both ground meteorological data and reconstructed PAR (Fig. 4). Dramatic reductions of GPP found in the summertime NON-DAO were smoothened in FILL-NWS, likely due to the effect of the reconstructed FPAR. The summertime maximum GPP decreased from approximately $6 \mathrm{gC} \mathrm{m}^{-2}$ $\mathrm{d}^{-1}$ in NON-DAO to $5 \mathrm{gC} \mathrm{m}^{-2} \mathrm{~d}^{-1}$ in FILL-NWS, due to lower values of VPD and $\mathrm{R}_{\mathrm{s}}$ at the weather stations than the DAO data.

Overall, the uncertainty of the NON-DAO was evaluated by $+17 \%$ of the total RE to FILL-NWS. The RE, however, was variable with the biome types (Table 1). The highest RE was found in the evergreen forest biome $(+24 \%)$ and sequentially in order of the mixed forest (20\%), crop (11\%), and deciduous forest (6\%). Our results are compared with those from Kang et al. (2005b) who evaluated the RE associated with the DAO data and reported $40,32,17$, and $16 \%$ for the evergreen, mixed, and deciduous forest and crop biome types, respectively. Overall, they reported higher RE values than those reported in this study since they cal-

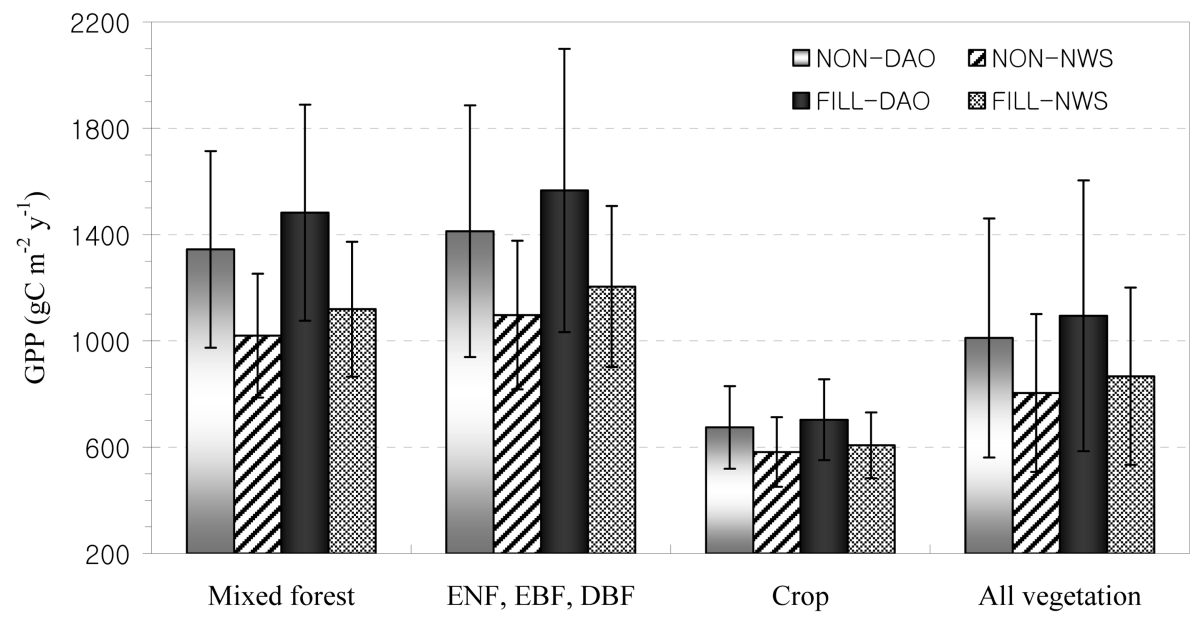

Fig. 5. Biome-specific comparisons of GPP estimations with different input data: NON-DAO indicates the original MODIS GPP with original FPAR and DAO data; NON-NWS, the original FPAR but ground meteorology; FILL-DAO, reconstructed FPAR but DAO data; and FILL-NWS, the reconstructed FPAR and ground meteorology, respectively. The GPP values were averaged for each biome types from 2001 to 2003. 
culated the RE based on the GPP estimates of the NON-NWS case that were lower than the FILL-NWS GPP.

One of the interesting results from our analysis is that the uncertainty of the MODIS GPP affects not only the absolute values of GPP but also the relative variation of the annual GPP for some biome types. In Table 1, the mixed (MF) and deciduous broadleaf (DBF) forests and crop biomes showed the maximum NON-DAO in 2002. However, the maximum GPPs for the biomes were found in 2003 in FILL-NWS, while the annual pattern of the evergreen forest was identical in both cases. The results indicate that the seasonality of errors contained in both the DAO and original MODIS FPAR significantly affects not only the seasonal GPP patterns (Fig. 4) but also the annual GPP variability (Table 1). Our interpretation is also supported by previous studies (Kang, 2005; Kang et al., 2005b) which indicate the importance of the summertime DAO VPD and FPAR errors in MODIS GPP estimations.

The uncertainty analyses on four different GPP estimates were integrated in Fig. 5. In comparison with FILL-NWS, NON-DAO showed higher GPP by 144 $\mathrm{gC} \mathrm{m}^{-2} \mathrm{y}^{-1}$; NON-NWS, lower by $63 \mathrm{gC} \mathrm{m}^{-2} \mathrm{y}^{-1}$; FILL-DAO, higher by $228 \mathrm{gC} \mathrm{m}^{-2} \mathrm{y}^{-1}$ than FILLNWS. The comparisons indicated that the errors in the meteorological data and the cloud-contaminated FPAR resulted in the respective overestimation (with RE of $26 \%$ ) and underestimation (with RE of $-7 \%$ ) of GPP estimates with the overall GPP overestimation of $17 \%$. The comparative patterns of relative errors were identical for every biome types. Among the biome types, however, the mixed forest biome showed the highest RE of $20,-9$, and $32 \%$ for NON-DAO, NON-NWS, and FILL-DAO, respectively. The result was contrary to the highest RE in evergreen forests reported by Kang (2005), who only considered the errors associated with FPAR and attributed his result to longer growing seasons of evergreen forests experiencing more cloudy days. Our result of the highest RE in the mixed forest, therefore, implies the more significant effect of the growing season uncertainty in DAO meteorology on the estimation of GPP.

\section{SUMMARY AND CONCLUSIONS}

The MODIS GPP provides a new opportunity to monitor global vegetation productivity. Because the product is based on a simplified light use efficiency model operated with input data of surface meteorology and FPAR, the reliability of the MODIS GPP is strongly affected by the use of reliable input data (Zhao et al., 2005; Heinsch et al., 2006). Though MODIS GPP currently provides periodic images of vegetation productivity, the reliability should be evaluated and the error sources of the MODIS GPP should be investigated before its practical application in land surface vegetation production in forested and/or cultivated areas. In particular, compared to the global application, the regional application of the MODIS GPP product is easier to improve by using improved meteorological variables and by applying better manipulation of cloud contamination of FPAR.

In the study area, the overall uncertainty of the official MODIS GPP was $17 \%$, compared to the enhanced GPP estimated with ground meteorological data and cloud-free FPAR. The errors associated with DAO meteorology and cloud-contaminated FPAR affected not only the absolute values of GPP but also the relative variation of the annual GPP for some biome types. For example, mixed and deciduous forest and crop biomes showed the maximum official MODIS GPP in 2002, but the maximum GPP values were found in 2003 in the enhanced GPP.

The primary error source was associated with DAO meteorology whereas the cloud-contaminated FPAR was a secondary source for the integrated uncertainty of the official MODIS GPP. On the other hand, each biome type showed a different GPP uncertainty. The largest relative error of the official MODIS GPP was found in the mixed forest biome $(\mathrm{RE}=20 \%)$. The mean relative error for all forest biomes was $19.6 \%$, whereas the errors for the crop land cover was $11 \%$.

In conclusion, our integrative analyses indicate that considerable uncertainties are embedded in the official MODIS GPP which should be corrected before its application for monitoring of vegetation productivity in Korea. It is therefore necessary to build reliable meteorological data and cloud-free FPAR, and to further investigate uncertainties associated with both biome-specific ecophysiological parameters and model algorithms.

\section{적 요}

현재 $1 \mathrm{~km}$ 해상도의 Moderate Resolution Imaging Spectroradiometer(MODIS) 총일차생산성(GPP) 영상이 8일 간격으로 제공되고 있다. 본 연구에서 MODIS GPP 산출에 사용되는 입력기상(DAO)자료와 광합성유 
효복사흡수율(FPAR) 자료의 오차를 정량화 하였고, 이 들 오차가 MODIS GPP의 불확실성에 미치는 영향을 분석하였다. 입력자료의 평가를 위해 지상기상관측소의 기상자료를 사용하였고, 구름효과 등을 저감한 FPAR 의 시계열을 복원하였다. 평가 결과 입력자료의 오차는 MODIS GPP에서 $17 \%$ 정도 과대평가되었다. 두 오차 중에서 기상자료의 오차가 주요 원인이었으며, FPAR 의 오차는 부차적인 것으로 판명되었다. 다양한 토지피 복 중에서 혼효림의 MODIS GPP 오차가 약 $20 \%$ 로 가장 크고, 농경지는 약 $11 \%$ 의 오차를 보였다. 입력 자료에 의한 MODIS GPP의 오차는 GPP의 계절변화 뿐만 아니라 연간 GPP 변화에도 상이한 결과를 초래 하였다. 따라서 MODIS GPP에 내재한 오차는 상당하 다고 판단되며, 향후 GPP 모니터링에 응용하기 위해 선 상기 기술한 오차 요인들을 저감한 입력자료에 의 거해 MODIS GPP를 재가공할 필요가 있다.

\section{ACKNOWLEDGEMENTS}

This work was supported by the Sustainable Water Resources Research Center of 21st Century Frontier Research Program (Grant code: 1-8-2); The Eco-Technopia 21 Project of the Ministry of Environment; Long-Term Monitoring and Assessment of Climate Change Impact on Forest Ecosystem Project of Korea Forest Research Institute; and the BK21 program of the Ministry of Education and Human Resources Development of Korea. The authors would like to thank two anonymous reviewers for their helpful comments.

\section{REFERENCES}

Churkina, G., S. W. Running, A. L. Schloss, and The Participants of the Potsdam NPP Model Intercomparison, 2000: Comparing global models of terrestrial net primary productivity (NPP): the importance of water availability. Global Change Biology 5 (Suppl. 1), 46-55.

Friend, A. D., A. Arneth, N. Y. Kiang, M. Lomas, J. Ogee, C. Rodenbeck, S. W. Running, J-D. Santaren, S. Sitch, N. Viovy, F. I. Woodwards, and S. Zaehle, 2007: Fluxnet and modeling the global carbon cycle. Global Change Biology 13, 610-633.

Heinsch, F. A., M. Reeves, C. F. Bowker, P. Votava, S. Kang, C. Milesi, M. Zhao, J. Glassy, W. M. Jolly, J. S. Kimball, R. R. Nemani, and S. W. Running, 2003: User's guide: GPP and NPP (MOD17A2/A3) products, NASA MODIS Land Algorithm. http://www.forestry.umt.edu/ntsg/.

Heinsch, F. A., M. Zhao, S. W. Running, J. S. Kimball, R. R. Nemani, K. J. Davis, P. V. Bolstad, B. D. Cook, A. R. Desai,
D. M. Ricciuto, B. E. Law, W. C. Oechel, H. J. Kwon, H. Luo, S. C. Wofsy, A. L. Dunn, J. W. Munger, D. D. Baldocchi, L. Xu, D. Y. Hollinger, A. D. Richardson, P. C. Stoy, M. B. S. Siqueira, R. K. Monson, S. P. Burns, and L. B. Flanagan, 2006: Evaluation of remote sensing based terrestrial productivity from MODIS using regional tower eddy flux network obervations. IEEE Transactions on Geoscience and Remote Sensing 44(7), 1908-1925.

Kang, S., 2005: Application and cloud-originated error analysis of MODIS vegetation products for monitoring terrestrial ecosystems in the Korean Peninsula. Korean Journal of Ecology 28(4), 215-222.

Kang, S., S. W. Running, M. Zhao, J. S. Kimball, and J. Glassy, 2005a: Improving continuity of MODIS terrestrial phothsynthesis products using an interpolation schem for cloudy pixels. International Journal of Remote Sensing 28(6), 1659-1676.

Kang, S., Y. I. Kim, and Y. J. Kim, 2005b: Analysis on error sources of MODIS Gross Primary Productivity (GPP) product: I. Errors induced by using DAO meteorological data. Korean Journal of Agricultural and Forest Meteorology 7(2), 171-183.

Morisette, J. T., F. A. Heinsch, and S. W. Running, 2006: Monitoring global vegetation using moderate-resolution satellites. EOS Transactions 87, 568.

Myneni, R. B., S. Hoffman, Y. Knyazikhin, J. L. Privette, J. Glassy, Y. Tian, Y. Wang, X. Song, Y. Zhang, G. R. Smith, A. Lotsch, M. Friedl, J. T. Morisette, P. Votava, R. R. Nemani, and S. W. Running, 2002: Global products of vegetation leaf area and fraction absorbed PAR from year one of MODIS data. Remote Sensing of Environment 83, 214-231.

Nemani, R. R., C. D. Keeling, H. Hashimoto, W. M. Jolly, S. C. Piper, C. J. Tucker, R. B. Myneni, and S. W. Running, 2003: Climate-driven increases in global terrestrial net primary production from 1982 to 1999 . Science $\mathbf{3 0 0}$, 1560-1563.

Running, S. W., C. O. Justice, V. Salomonson, D. Hall, J. Barker, Y. J. Kaufmann, A. H. Strahler, A. R. Huete, J. P. Muller, J. P., V. Vanderbilt, Z. M. Wan, P. Teillet, and D. Carneggie, 1994: Terrestrial remote sensing science and algorithms planned for EOS/MODIS. International Journal of Remote Sensing 15, 3587-3620.

Running, S. W., R. R. Nemani, F. A. Heinsch, M. Zhao, M. C. Reeves, and H. Hashimoto, 2004: A continuous satellite-derived measure of global terrestrial primary production. BioScience 54, 547-460.

Potter, C. S., J. T. Randerson, C. B. Field, P. A. Matson, P. M. Vitousek, H. A. Mooney, and S. A. Klooster, 1993: Terrestrial ecosystem production: A process model based on global satellite and surface data. Global Biogeochemical Cycles 7, 811-841.

Prince, S. D., and S. N. Goward, 1995: Global primary production: A remote sensing approach. Journal of Bio- 
geography 22, 815-835.

Turner, D. P., W. D. Ritts, W. B. Cohen, S. T. Gower, S. W. Running, M. Zhao, M. H. Costa, A. Kirschbaum, J. M. Ham, S. R. Saleska, and D. E. Ahl, 2006: Evaluation of MODIS NPP and GPP products across multiple biomes. Remote Sensing of Environment 102, 282-292.

Zhao, M., F. A. Heinsch, R. R. Nemani, and S. W. Running, 2005: Improvements of the MODIS terrestrial gross and net primary production global data set. Remote Sensing of Environment 95, 164-175.

Zhao, M., S. W. Running, and R. R. Nemani, 2006: Sensitivity of Moderate Resolution Imaging Spectroradiometer (MODIS) terrestrial primary production to the accuracy of meterological reanalyses. Journal of Geophysical Research 111, G01002. 